Jurnal Pendidikan Bahasa Inggris Proficiency, Vol 4 No 1 Jan 2022

\title{
THE EFFECT OF TEACHER SELF-EFFICACY TOWARD ENGLISH LEARNING ACHIEVEMENT THROUGH MOTIVATION AS A MODERATOR VARIABLE
}

\author{
Adelia Shovi Damayanti, Mohammad Naim Musafik \\ adeliashovidamayanti@gmail.com,naimmusafik@uniska-kediri.ac.id
}

\begin{abstract}
In this study, the results of this research to analysis the effect of each variable. There are; (1) to analysis the significant effect of teacher self-efficacy toward English learning achievement, (2) to analysis the significant effect of motivation toward English learning achievement, (3) to analysis the significant effect of teacher selfefficacy toward motivation, (4) to analysis the significant effect of teacher selfefficacy toward English learning achievement through motivation. The results of this study (1) Teacher Self-Efficacy has no significant effect toward English Learning Achievement. (2) Motivation has significant effect toward English Learning Achievement. (3) Teacher Self-Efficacy has significant effect toward Motivation. And the last (4) Teacher Self-Efficacy toward English Learning Achievement through. Motivation has significant effect indirectly. The analysis of this study used descriptive quantitative approach as a research design. In this research questionnaire was used as a data collection instrument. The use of this questionnaire was intended to measure the variable (X1) teacher self-efficacy with a total of 16 questions in the form of statements, (X2) motivation with 15 questions in the form of statements and variable (Y) English learning achievement with a total of 15 questions in the form of statements. Using Google Form to find the significant effect of teacher self-efficacy toward English learning achievement through motivation as a moderator variable. In this study, researchers used a sample of $11^{\text {th }}$ grade students of SMA Negeri 7 Kediri to determine the effect of each variable to be studied. The total population of grade 11 students is 392 , so that from the total number of students, 198 students will be taken by random sampling.
\end{abstract}

Keywords: teacher self-efficacy, learning achievement, motivation

\section{INTRODUCTION}

Learning is a process of changing from not knowing to knowing. Learning activities are the most basic activities in the entire educational process in schools. According to Anurrahman (2016) learning is a process carried out by an individual who has the aim of transforming into new behaviour through floating experiences. This means learning an activity that is carried out consciously and leads to a change in the form of knowledge and skills. so that the success or failure of achieving educational goals really depends on how the learning process is experienced by students. Then the results of the learning process are called learning outcomes. 
In the world of education, learning achievement is very important and becomes one of the benchmarks in learning. Learning achievement is essentially a reflection of learning efforts. In line with the opinion of Pratiwi (2015) learning achievement is evidence of someone's success who has been achieved from the learning process. Learning achievement is the result achieved after students receive instruction within a certain time. The better the learning effort, the better achievement. In other words, learning achievement is a reflection of the ability to learn a subject. One of the characteristics of a quality human being is achievement.

The excellence of learning achievement is always a community assessment of a school or educational institution. This cannot be separated from the successful implementation of the teaching and learning process. The learning process is a complex activity. Not only teachers, students also determine whether learning occurs or not, so students are required to be active in learning.

In the learning and teaching process the role of teachers and students is a determining factor for successful learning. As for these factors, the first is external factors, namely teacher self-efficacy according to Gregory (2010), interpreting selfefficacy as self-confidence to understand their abilities so that they can exercise some form of control over their own interests and events around them. Teachers with self-efficacy have extra energy in using and empowering teaching resources effectively and efficiently for the success of students in learning. In addition, teachers with self-efficacy also show emotional maturity by not feeling stressed easily, resistant to pressure, and calm in the face of unpleasant situations. And the second is the internal factor, namely student motivation, according to Kompri (2016) motivation is an energy change in a person's personality characterized by the emergence of feelings and reactions to achieve goals through an interest in doing something. Motivation itself is characterized by the emergence of an inner drive that causes positive behaviour so that it can be directed to achieve a certain goal.

Both of these factors have an important role in student achievement. The teachers needs to think about how to attract attention and encourage student motivation in school, with the aim of creating interest, pleasure, interest, passion in students to carry out the learning process. This is in line with what was expressed by Iskandar (2012) that ideas and creative learning related to teacher efforts can generate student attention and motivation to learn. Students who have motivated will last longer on the task than students with low motivation. Highly motivated students will attribute their failure to a lack of effort so that they will redouble their efforts until they can succeed.

Based on the description above, the role of teacher self-efficacy and motivation can affect learning achievement. Based on this background, the study will focus on the effect and how much influence teacher self-efficacy toward English learning achievement through motivation using this type of quantitative research. Therefore, in this study the researcher raised the title "The Effect of Teacher Self-Efficacy toward English Learning Achievement through Motivation as a moderator variable among the students of SMA Negeri 7 Kediri". 
Jurnal Pendidikan Bahasa Inggris Proficiency, Vol 4 No 1 Jan 2022

\section{METHOD}

Research design in this study, researchers used descriptive and inferential quantitative approaches. The main characteristic of the quantitative approach is that the research data can be justified based on statistical data in this process of hypothesis testing. This study used quantitative methods because the observed symptoms were converted into numbers and analyzed using statistical data. According to Creswell (2012), quantitative research requires researchers to explain how variables affect other variables. According to Sugiono (2012) Variables are determined by researchers, and all things that exist in various forms are designed to obtain information about them and then draw conclusions. In this study, there are two variables, the independent variable and the dependent variable. Independent variables are the main variables that researchers expect to use in this study.

According to Sugiono (2012), the independent variable affects the dependent variable. It is usually represented by " $\mathrm{X}$ ", and the dependent variable is a variable that the researcher observes and measures to determine the influence of the independent variable. (Sugiono, 2012) pointed out that the dependent variable is a variable affected by the existence of the independent variable. This is represented by "Y". The dependent variable in this study is "English learning achievement".

The data collection technique uses a questionnaire to be carried out by the respondent. This research method provides this approach because researchers need to prove the effect of each variable and to determine the effect of teacher selfefficacy toward English learning achievement through motivation as a moderator variable. The sample and population used random sampling because students fill out a questionnaire using Google Form so that the data collected is randomized. Then the data were distributed at the same time and the same link to all $11^{\text {th }}$ grade students of SMA Negeri 7 Kediri with a total population of 392 then a sample of 198 was taken. The use of this questionnaire was intended to measure the variable (X1) teacher self-efficacy with a total of 16 questions in the form of statements, (X2) motivation with 15 questions in the form of statements and (Y) English learning achievement with a total of 15 questions in the form of statements.

\section{RESULTS AND DISCUSSION}

In this study, after the data was collected then the data was processed and analysis using IBM SPSS version 26. The results of the study of validity, reliability, normality, linearity, multicollinearity, heteroscedasticity was valid and the hypotheses test are explained as follows;

\section{Results}

1. The effect of Teacher Self-Efficacy toward English Learning Achievement

Table 4.10 Model Summary of Teacher Self-Efficacy toward English Learning Achievement

\begin{tabular}{|c|c|c|c|c|}
\hline \multicolumn{5}{|c|}{ Model Summary } \\
\hline Model & $\mathrm{R}$ & R Square & $\begin{array}{l}\text { Adjusted R } \\
\text { Square }\end{array}$ & $\begin{array}{l}\text { Std. Error of the } \\
\text { Estimate }\end{array}$ \\
\hline 1 & $.095^{\mathrm{a}}$ & .009 & .004 & 9.195 \\
\hline
\end{tabular}


According to the table above, the value of $\mathrm{R}$ Square is 0.009 . This means that the partial effect of teacher self-efficacy has a contribution of $0.9 \%$ toward English learning achievement.

Table 4.12 Coefficients Table of Teacher Self-efficacy toward English Learning Achievement Coefficients $^{\mathrm{a}}$

\begin{tabular}{|c|c|c|c|c|c|c|}
\hline \multirow[b]{3}{*}{ Model } & & & 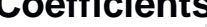 & \multirow{3}{*}{$\begin{array}{c}\text { Standardized } \\
\text { Coefficients } \\
\text { Beta }\end{array}$} & \multirow[b]{3}{*}{ t } & \multirow[b]{3}{*}{ Sig. } \\
\hline & & Unstandardized & Coefficients & & & \\
\hline & & B & Std. Error & & & \\
\hline \multirow[t]{2}{*}{1} & (Constant) & 46.421 & 5.807 & & 7.994 & .000 \\
\hline & $\mathrm{X} 1$ & .115 & .086 & .095 & 1.340 & .182 \\
\hline
\end{tabular}

a. Dependent Variable: $Y$

According to table coefficients bellow, the number of constant (a) in unstandardized coefficient is 46,421 . It means if the value of teacher self efficacy is 0 , thus the value of English learning achievement is 46,421 and coefficient regression of teacher self-efficacy (b) is 0,115 . It means if teacher self-efficacy has whole increase, thus English learning achievement will increase about 0,115 and the score of " $t$ " count is 1,340 .

$\mathrm{T}$ table is measured on $\alpha=5 \%: 2=2,5 \%$ with degree freedom (df) $n-2$ or $198-2=196$. The significant of test is 0,025 . Meanwhile the score of " $t$ " table is 1,972. It shown that $\mathrm{t}$ count $(1,340)<\mathrm{t}$ table $(1,972)$. From the value, it can concluded that Ho is accepted, it means there is no partial effect of teacher selfefficacy toward English learning achievement.

2. The Effect of Motivation toward English Learning Achievement

Table 4.13 Model Summary of Motivation toward English Learning Achievement Model Summary

\begin{tabular}{l|l|l|l|l} 
& & & \\
Model & $\mathrm{R}$ & $\mathrm{R}$ Square & $\begin{array}{c}\text { Adjusted R } \\
\text { Square }\end{array}$ & $\begin{array}{c}\text { Std. Error of the } \\
\text { Estimate }\end{array}$ \\
\hline 1 & $.409^{\mathrm{a}}$ & .167 & .163 & 8.428 \\
\hline $\begin{array}{l}\text { a. Predictors: (Constant), X2 } \\
\text { b. Dependent Variable: } \mathrm{Y}\end{array}$
\end{tabular}

According to the table above, the value of $\mathrm{R}$ Square is 0,167 . It means that the partial effect of teacher self-efficacy has a contribution of 16,7\% toward English learning achievement.

Table 4.15 Coefficients Table of Motivation toward English Learning Achievement Coefficients $^{\mathrm{a}}$

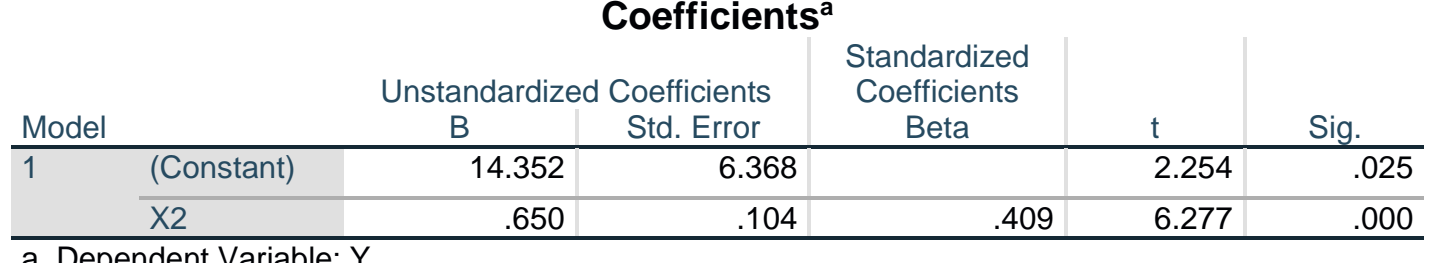


Based on table coefficients bellow, the number of constant constant (a) in unstandardized coefficient is 14,352 . It means if the value of motivation is 0 , thus the value of English learning achievement is 14,352 and coefficient regression of teacher self-efficacy (b) is 0,650. It means if motivation has whole increase, thus English learning achievement will increase about 0,650 and the score of " $t$ " count is 6,277 .

T table is measured on $\alpha=5 \%: 2=2,5 \%$ with degree freedom (df) $n-2$ or $198-2=196$. The significant of test is 0,025 . Meanwhile the score of " $t$ " table is 1,972 . It shown that $t$ count $(6,277)>t$ table $(1,978)$. From the value, it can conclude that $\mathrm{Ha}$ is accepted, it means there is partial effect of motivation toward English learning achievement.

\section{The Effect of Teacher Self-Efficacy toward Motivation}

Table 4.16 Model Summary of Teacher Self-Efficacy toward Motivation

\begin{tabular}{|c|c|c|c|c|}
\hline \multicolumn{5}{|c|}{ Model Summary } \\
\hline Model & $\mathrm{R}$ & R Square & $\begin{array}{l}\text { Adjusted R } \\
\text { Square }\end{array}$ & $\begin{array}{c}\text { Std. Error of the } \\
\text { Estimate }\end{array}$ \\
\hline 1 & $.300^{\mathrm{a}}$ & .090 & .085 & 5.548 \\
\hline
\end{tabular}

According to the table above, the value of $\mathrm{R}$ Square is 0,090 . It means that the partial effect of teacher self-efficacy has a contribution of $9,0 \%$ toward motivation.

Table 4.18 Coefficients Table of Teacher Self-Efficacy toward Motivation Coefficients $^{a}$

\begin{tabular}{|c|c|c|c|c|c|c|}
\hline \multirow{2}{*}{\multicolumn{2}{|c|}{ Model }} & \multicolumn{2}{|c|}{ Unstandardized Coefficients } & \multirow{2}{*}{$\begin{array}{c}\text { Standardized } \\
\text { Coefficients } \\
\text { Beta } \\
\end{array}$} & \multirow[b]{2}{*}{$t$} & \multirow[b]{2}{*}{ Sig. } \\
\hline & & $\mathrm{B}$ & Std. Error & & & \\
\hline \multirow[t]{2}{*}{1} & (Constant) & 45.941 & 3.504 & & 13.111 & .000 \\
\hline & $\mathrm{X} 1$ & .227 & .052 & .300 & 4.396 & .000 \\
\hline
\end{tabular}

Based on table coefficients bellow, the number of constant (a) in unstandardized coefficient is 45,941. It means if the value of teacher self-efficacy is 0 , thus the value of motivation is 45,941 and coefficient regression of teacher self-efficacy (b) is 0,227 . It means if teacher self-efficacy has whole increase, thus motivation will increase about 0,227 and the score of " $t$ " count is 4,396.

T table is measured on $\alpha=5 \%: 2=2,5 \%$ with degree freedom (df) $n-2$ or $198-2=196$. The significant of test is 0,025 . Meanwhile the score of " $t$ " table is 1,972 . It shown that $t$ count $(4,396)>t$ table $(1,978)$. From the value, it can conclude 
that Ha is accepted, it means there is partial effect of teacher self-efficacy toward motivation.

4. The Effect of Teacher Self-Efficacy toward English Learning Achievement through Motivation

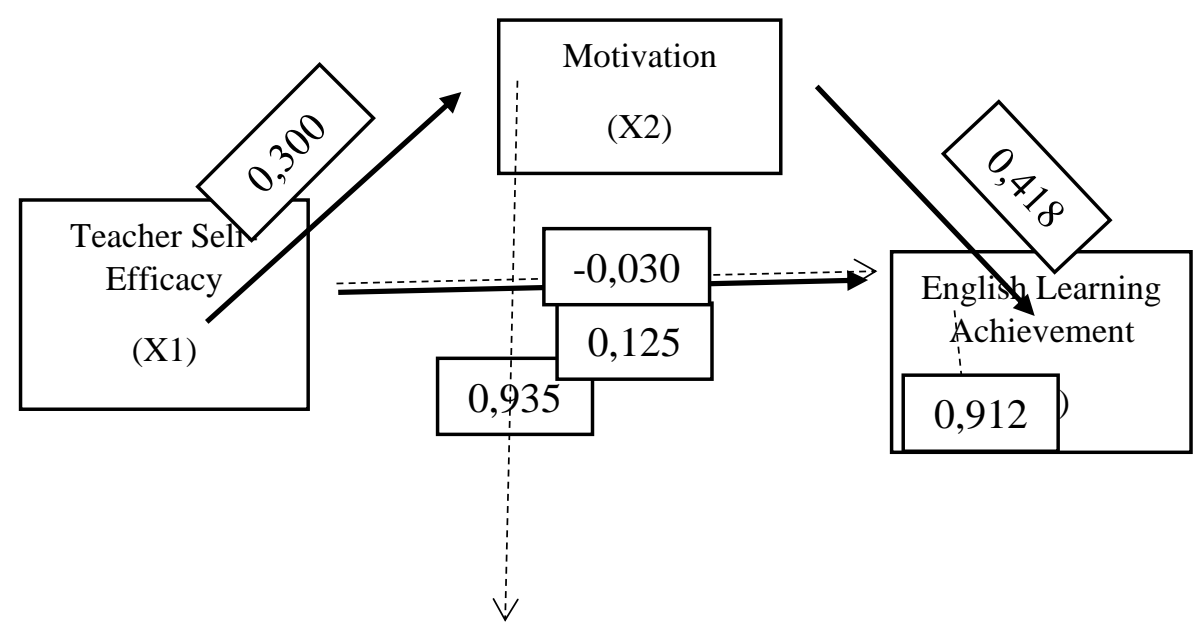

Figure 4.4 The Result of Concept Mapping

The research result indicated that direct effect of $X 1$ through $\mathrm{X} 2$ was 0,300 , while the indirect effect $\mathrm{X} 1$ toward $\mathrm{Y}$ is the multiplication between beta value of $\mathrm{X} 1$ and $\mathrm{X} 2$ toward $\mathrm{Y}(0,300 \times 0,418=0,125)$. The total effect of $\mathrm{X} 1$ toward $\mathrm{Y}$ is calculated through the sum between the beta value of direct effect and indirect effect $(-0,030+0,125=0,095)$. Based on the results above, the value of direct effect was 0,095 while the value of indirect effect was 0,125 . It means that indirect effect is more than direct effect, which indicated X1 indirectly had impact toward Y.

\section{Discussion}

1. The Effect of Teacher Self-Efficacy toward English Learning Achievement

Based on table coefficients in partial effect of teacher self-efficacy toward English learning achievement it shown that $t$ count $(1,340)<t$ table $(1,972)$. From the value, it can concluded that Ho is accepted, it means there is no partial effect of teacher self-efficacy toward English learning achievement.

Previous research is encouraging (Fayetteville 2015) the results show that the correlation coefficient is 0,329 , and the significant value is 0,071 , which is greater than $\mathrm{a}=0.05$. Therefore, the analysis shows that there is no significant effect between fifth-grade science teachers' sense of efficacy and student performance. In the research question, the influence of teacher's sensory efficacy beliefs on students' 
scientific achievement shows that there is no significant influence between the two variables.

In the 8th grade math, writing, and English tests, there was a significant positive correlation between the effectiveness of group teachers and student performance (Megan, 2010). This relationship is affected by some teacher effectiveness indicators and secondary factors, as well as the length of teaching experience (Ryung, 2018). However, in this study, the results contradicted previous studies. In this study, data show that teacher self-efficacy has no significant effect on English learning achievement..

In research, the effect of teacher self-efficacy on English learning achievement is not proven. Especially during the Covid 19 pandemic, teachers could not transfer their knowledge by interacting effectively so that the teacher's influence on learning did not have a impact on student achievement.

2. The Effect of Motivation toward English Learning Achievement

Based on table coefficients in partial effect of motivation toward English learning Achievement it shown that $t$ count $(6,277)>t$ table $(1,972))$. From the value, it can concluded that $\mathrm{Ha}$ is accepted, it means there is partial effect of motivation toward English learning achievement.

Previous research has shown that. Students' intrinsic motivation has a positive and significant impact on their English learning performance, and the $r$ count value is greater than the table (0.287> 0.207 (Ghinaib, 2018). According to Munandar (2014), achievement motivation is a powerful driving force for success. Individuals only focus on pursuing achievement instead of rewarding success. Individuals will also be more eager to do better and always fulfill their duties and responsibilities. From this definition it can be concluded that achievement motivation is the effort and responsibility of each individual by using all abilities to achieve learning achievement.

In this study, the effect of motivation on English learning achievement can be proven by data that shows a partially significant influence between the two variables. Students who are motivated to learn will definitely be motivated because they have learning goals.

\section{The Effect between Teacher Self-Efficacy and Motivation}

Based on table coefficients in partial effect of teacher self-efficacy toward motivation it shown that $\mathrm{t}$ count $(4,396)>\mathrm{t}$ table $(1,978)$. From the value, it can concluded that Ha is accepted, it means there is partial effect of teacher self-efficacy toward motivation.

These findings reveal the importance of ability or teaching effectiveness and confidence or personal effectiveness beliefs, which in turn enhance the motivation of students (Iftikhar, 2011). Motivation can be influenced by internal and external students. In the process of learning and teaching, students have a close relationship with teachers. Teachers are catalysts, so they can inspire students to do their best to succeed. Teachers also play a role in ensuring that students can achieve their goals. 
In this study, the effect of teacher self-efficacy toward motivation can be proven by data that shows a partially significant effect between the two variables. teachers who have good efficacy can trigger student motivation because students will feel that the teacher has superior abilities, so that students have a sense of trust in teacher efficacy.

4. The Effect of Teacher Self-Efficacy toward English Learning Achievement through Motivation

The research result indicated that direct effect of $\mathrm{X} 1$ through $\mathrm{X} 2$ was 0,300 , while the indirect effect $\mathrm{X} 1$ toward $\mathrm{Y}$ is the multiplication between beta value of $\mathrm{X} 1$ and $\mathrm{X} 2$ toward $\mathrm{Y}(0,300 \times 0,418=0,125)$. The total effect of $\mathrm{X} 1$ toward $\mathrm{Y}$ is calculated through the sum between the beta value of direct effect and indirect effect $(-0,030+0,125=0,095)$. Based on the results above, the value of direct effect was 0,095 while the value of indirect effect was 0,125 . It means that indirect effect is more than direct effect, which indicated X1 indirectly had impact toward Y.

Based on research data, the effect of teacher self-efficacy toward English learning achievement through motivation has an indirect effect. The variable between teacher self-efficacy and English learning achievement directly has a smaller effect, while the variable teacher self-efficacy toward English learning achievement through motivation has a greater indirect effect. From these explanations, it can be concluded that motivation as a moderator variable has a greater indirect role on learning achievement.

\section{CONCLUSION}

From the research result, it can be conclude that variable Teacher SelfEfficacy has no significant effect toward English Learning Achievement. Motivation has significant effect toward English Learning Achievement. Teacher Self-Efficacy has significant effect toward Motivation. And the last Teacher SelfEfficacy toward English Learning Achievement through Motivation has significant effect indirectly.

From the research result, it can be suggested that for students from this research students are expected to be able to increase their motivation on English learning achievement. For teachers, to pay more attention to their teacher selfefficacy toward learning achievement. For headmaster, the results of this research can be used as input and consideration to improve English learning achievement. For researchers, this research can be used as basic research for future research related to improving students' achievement.

\section{REFERENCES}

Annurahman. (2016). Belajar dan Pembelajaran. Bandung: Alfabeta.

Creswell, John W. (2012). Educational research: planning, conducting, evaluating, quantitative and qualitative research (Fourth Edition). United State of America: Pearson Education Inc, 36(7), 69-90.Sugiono (2012). Memahami Penelitian Kuantitatif, Bandung: Alfabeta 
Jurnal Pendidikan Bahasa Inggris Proficiency, Vol 4 No 1 Jan 2022

Gregory J \& Feist, (2010). Teori Kepribadian, Theories of Personality Book 2 Edition 7 Jakarta: Salemba Humanika.

Iskandar. (2012). Psikologi Pendidikan. Jakarta: Referensi.

Iftikhar (2011) Effect of Teacher Efficacy Beliefs on Motivation. University of Management and Technology, Lahore, Pakistan. Journal of Behavioural Sciences, 21(2) 1-2.

Kompri. (2016). Motivasi Pembelajaran Perspektif Guru dan Siswa. Bandung: PT Remaja Rosdakarya Offset

Megan (2010) Fostering Students' Learning: The Relatoanship of Collective Teacher Efficacy and Students Achievement. Accessed on 28 March 2021 From, https://doi.org/10.1080/15700760490503706

Munandar (2019), Mengembangkan Bakat Anak, Jakarta : Gramedia

Pratiwi, Komari, N. (2015). Pengaruh Tingkat Pendidikan, Perhatian Orang Tua, Dan Minat Belajar Siswa Terhadap Prestasi Belajar Bahasa Indoonesia Siswa SMK Kesehatan di Kota Tangerang. Jurnal Penelitian Pendidikan. 11(2) 38.

Ryung K. K., \& Seo, E. H. (2018). The relationship between teacher efficacy and students' academic achievement: A meta-analysis. Social Behavior and Personality: An international journal, 46(4), 529-540.

Sugiyono. (2013). Metode Penelitian Kuantitatif, Kualitatif dan R\&D. Bandung: Alfabeta.CV

Sugiono (2012). Memahami Penelitian Kuantitatif, Bandung: Alfabeta 